\title{
DAYA HAMBAT EKSTRAK BAHAN AKTIF BIJI PICUNG (Pangium edule Reinw.) TERHADAP PERTUMBUHAN BAKTERI PENGHASIL HISTAMIN
}

\author{
Arifah Kusmarwati ${ }^{\star}$ dan Ninoek Indriati*)
}

\begin{abstract}
ABSTRAK
Penelitian ini dilakukan untuk mengetahui kemampuan ekstrak bahan aktif biji picung segar dan terfermentasi sebagai penghambat pertumbuhan bakteri penghasil histamin. Bakteri penghasil histamin yang diuji daya hambatnya meliputi Morganella morganii, Raoultella terigena, Enterobacter sp., Microbacterium testaceum, Staphylococcus sp., dan Micrococcus diversus. Pengujian daya hambat dilakukan dengan metode difusi pada lempeng agar. Hasil penelitian menunjukkan bahwa ekstrak akuades dan ekstrak etanol $50 \%$ dari biji picung segar mampu menghambat pertumbuhan bakteri penghasil histamin, sedangkan ekstrak n-heksana tidak memiliki daya hambat. Sementara itu, ekstrak akuades, etanol 50\%, maupun n-heksana dari biji picung terfermentasi tidak mampu menghambat pertumbuhan bakteri penghasil histamin.
\end{abstract}

\begin{abstract}
The inhibition rate of the active compound of Pangium edule Reinw. seeds extract on the growth of histamine producing bacteria. By: Arifah Kusmarwati and Ninoek Indriati

An experiment was conducted to assess the ability of fresh and fermented Pangium edule Reinw. seeds extract to inhibit the growth of histamine producing bacteria. Histamine producing bacteria tested were Morganella morganii, Raoultella terigena, Enterobacter sp., Microbacterium testaceum, Staphylococcus sp., and Micrococcus diversus. Assessment of inhibition was determined by an agar diffusion method. The results showed that distilled water and $50 \%$ ethanol extracts of fresh Pangium edule Reinw. seed could inhibit the growth of histamine producing bacteria, whereas, the n-hexane extract did not show inhibition. On the other hand, fermented Pangium edule Reinw. seeds extracts using distilled water, 50\% ethanol, and n-hexane showed no inhibition on the growth of histamine producing bacteria
\end{abstract}

KEYWORDS: the inhibition rate, Pangium edule Reinw., histamine producing bacteria

\section{PENDAHULUAN}

Histamin atau dikenal sebagai [2-(4imidazolyl)ethylamine] terbentuk dari dekarboksilasi oleh enzim yang terdapat secara alami dalam jaringan daging ikan. Jumlah histamin yang dihasilkan melalui aktivitas enzim selama proses autolisis sangat rendah bila dibandingkan dengan histamin yang dihasilkan oleh aktivitas bakteri selama proses pembusukan berlangsung. Di bawah kondisi optimum, jumlah histamin yang dihasilkan melalui autolisis biasanya kurang dari 10-15 mg/100 g daging ikan. Selain itu produksi histamin juga dipengaruhi oleh suhu dan $\mathrm{pH}$ lingkungan (Witiak et al., 1981; Kimata, 1961 dalam Rispayeni, 2005). Sementara itu, Nahla et al. (2005) telah melaporkan bahwa jumlah histamin yang berasal dari beberapa ikan spesies lokal di Mesir sebesar 7-26 mg/100 g daging ikan, sedangkan jumlah histamin yang berasal dari ikan impor berkisar antara $18-50 \mathrm{mg} / 100 \mathrm{~g}$ daging ikan. Isolat-isolat bakteri yang berasal dari sampel-sampel tersebut antara lain adalah Micrococcus sp., Planococcus sp., Morganella morganii, Enterobacter aerogenes, Klebsiella pneumoniae, Vibrio parahaemolyticus, Vibrio alginolyticus, Vibrio angillarum, Proteus vulgaris, dan Aeromonas spp.

Histamin merupakan salah satu senyawa yang seringkali dianggap sebagai penyebab utama keracunan makanan yang berasal dari ikan dan produk perikanan (Atmadjaja, 1994 dalam Rispayeni, 2005). Keracunan histamin ini biasanya terjadi setelah mengkonsumsi ikan skombroid atau produk perikanan yang mengandung kadar histamin yang cukup tinggi seperti tuna, mackerel, dan bonito, oleh karena itu dikenal sebagai scombroid poisoning (keracunan skombroid) (Jay, 1996; Sophia, 2007). Meskipun demikian, banyak ikan-ikan non scombroid yang juga dapat menyebabkan keracunan histamin, seperti mahi-mahi (Niven et al., 1981). Jenis-jenis ikan ini mengandung histidin bebas dalam jumlah besar pada jaringan dagingnya, yang pada kondisi tertentu dapat diubah menjadi histamin oleh enzim L-histidin dekarboksilase yang dihasilkan oleh bakteri (Sally et al., 1980).

\footnotetext{
*) Peneliti pada Balai Besar Riset Pengolahan Produk dan Bioteknologi Kelautan dan Perikanan, DKP
} 
Bakteri yang memiliki enzim histidin dekarboksilase atau biasa disebut bakteri penghasil histamin, sebagian besar termasuk ke dalam famili Enterobacteriaceae. Jenis bakteri tersebut antara lain: Morganella morganii, Klebsiella pneumoniae, Hafnia alvei, Citrobacter freundii, Clostridium perfringens, Enterobacter aerogenes, Vibrio alginolyticus, dan Proteus sp. Hampir semua strain M. morganii mampu menghasilkan histamin hingga mencapai $400 \mathrm{mg} \%$ (Jay, 1996; Indriati et al., 2006). M. morganii, Proteus sp., dan Klebsiella sp. merupakan bakteri penghasil histamin utama dan sering ditemukan pada kasuskasus keracunan histamin setelah mengkonsumsi ikan tuna (Wei et al., 1990 dalam Rispayeni, 2005), sementara $\mathrm{H}$. alvei dan Proteus sp. adalah penghasil histamin lemah (Jay, 1996). Niven et al., 1981 melaporkan bahwa bakteri penghasil histamin yang paling banyak terdapat pada tuna segar, mahi-mahi, dan mackerel adalah $M$. morganii, diikuti oleh Klebsiella pneumoniae, E. coli, Enterobacter aerogenes, Enterobacter cloacae, Proteus sp., Edwardsiella sp., dan Vibrio spp. Pada kasus keracunan skombroid yang berkaitan dengan konsumsi tuna sashimi, telah ditemukan adanya bakteri $K$. pneumoniae, dengan kandungan histamin sebesar 442 mg\% (Jay, 1996). Biji picung segar secara kimiawi mengandung senyawa saponin, flavonoid, dan polifenol (Anon., 2008). Aminah (2008) melaporkan bahwa ekstrak dan serbuk biji picung melalui uji fitokimia terbukti mengandung senyawa minyak atsiri, asam lemak, sterol, flavonoid, tanin, gula pereduksi, saponin, emodol, dan poliuronida. Beberapa hasil penelitian melaporkan bahwa komponen biji picung yang mempunyai peranan dalam pengawetan ikan adalah asam sianida serta asam khaulmograt dan asam hidnokarpat (Subariah et al., 1971 dalam Indriyati, 1987). Senyawa lain yang diduga bersifat sebagai antibakteri pada biji picung adalah tanin (Ismaini, 2007). Tanin merupakan senyawa golongan fenol polimer yang mampu mempresipitasi gelatin dari larutannya. Tanin bersifat toksik terhadap jamur, khamir, dan bakteri. Tanin dilaporkan bersifat bakteriostatik atau bakterisida terhadap Staphylococcus aureus (Cowan, 1999; Akiyama et al., 2001). Selain itu pada minyak biji picung terfermentasi terdapat senyawa asam lemak yakni asam oleat, linoleat, dan asam palmitat (Widyasari, 2005).

Masih terbatasnya informasi ilmiah mengenai kemampuan ekstrak bahan aktif biji picung sebagai penghambat bakteri penghasil histamin, menjadi dasar dilakukannya penelitian mengenai uji daya hambat ekstrak bahan aktif biji picung ini terhadap bakteri penghasil histamin.

\section{BAHAN DAN METODE}

\section{Bahan}

Penelitian ini menggunakan biji picung (Pangium edule Reinw.) segar dan terfermentasi. Biji picung terfermentasi (kluwek) adalah biji picung yang telah mengalami proses fermentasi secara alami. Biji picung segar maupun terfermentasi diperoleh dari lokasi yang sama, yaitu dari desa Pabuaran, Cileungsi, Bogor. Bahan kimia yang digunakan berupa pelarut etanol $50 \%$, n-heksana, dapar fosfat $\mathrm{pH} 7$, dan $\mathrm{NaCl} 0,9 \%$. Bakteri uji yang digunakan adalah bakteri penghasil histamin yang diperoleh dari laboratorium mikrobiologi Balai Besar Riset Pengolahan Produk dan Bioteknologi (BBRP2B), Departemen Kelautan dan Perikanan, Jakarta yang diisolasi dari ikan peda oleh Indriati et al. (2006). Jenis-jenis bakteri tersebut adalah Enterobacter sp., Morganella morganii, Raoultella terigena, Microbacterium testaceum, Staphylococcus sp., Enterobacter sp., dan Micrococcus diversus. Kloramfenikol (Indofarma) digunakan sebagai antibiotik pembanding dengan konsentrasi $10 \mathrm{mg} / \mathrm{mL}$. Nutrient Agar (NA) (Difco) digunakan sebagai media pertumbuhan dan pemeliharaan bakteri, sedangkan Mueller Hinton Agar (MHA) (Difco) digunakan sebagai medium uji daya hambat bakteri.

\section{Metode}

\section{Ekstraksi komponen bioaktif}

Ekstraksi dimulai dengan pengumpulan daging biji picung untuk dikeringbekukan dengan freeze dryer dan digiling halus. Selanjutnya $200 \mathrm{~g}$ serbuk biji picung segar dan biji picung terfermentasi masing-masing dilarutkan dalam $1.000 \mathrm{~mL}$ akuades, dan dimaserasi selama $3 \times 24$ jam. Ekstrak kasar yang diperoleh disaring dengan kertas Whatman no. 42 dan dipekatkan dengan evaporator pada suhu kamar $\left(25^{\circ} \mathrm{C}\right)$. Ampas dari ekstrak akuades dilarutkan dalam $1.000 \mathrm{~mL}$ etanol $50 \%$ dan dimaserasi kembali dengan cara yang sama sehingga diperoleh ekstrak etanol $50 \%$. Selanjutnya ampas dari ekstraksi etanol $50 \%$ dimaserasi kembali menggunakan $1.000 \mathrm{~mL}$ n-heksana sehingga diperoleh ekstrak n-heksana. Ketiga macam ekstrak yang diperoleh, dimasukkan ke dalam botol tertutup dan disimpan dalam freezer pada suhu $-5^{\circ} \mathrm{C}$ sampai saat akan digunakan (Darusman et al., 1994; Harborne, 1998).

\section{Pembuatan larutan stok dan larutan uji}

Larutan stok dibuat dengan cara penimbangan ekstrak akuades, etanol $50 \%$, dan n-heksana masingmasing sebanyak $800 \mathrm{mg}$ dan dilarutkan dengan pelarut masing-masing kemudian ditambah dengan 
dapar fosfat $\mathrm{pH} 7$ hingga volume $10 \mathrm{~mL}$. Larutan stok yang memiliki konsentrasi $80 \mathrm{mg} / \mathrm{mL}$ tersebut, selanjutnya diencerkan secara serial hingga mencapai konsentrasi 10; 20; 30; 40; 50; 60; 70; dan $80 \mathrm{mg} / \mathrm{mL}$ (Anon., 1995).

\section{Pengujian daya hambat bakteri}

Pengujian antibakteri dilakukan untuk menentukan kemampuan membunuh atau menghambat pertumbuhan mikroorganisme hidup (Wangidjaja, 2004). Bakteri uji untuk pengujian daya hambat, dipersiapkan dengan cara ditumbuhkan pada media Nutrient Agar selama 24 jam pada suhu $37^{\circ} \mathrm{C}$. Bakteri yang telah tumbuh pada media NA kemudian diambil satu ose untuk ditumbuhkan pada media Nutrient Broth kemudian diinkubasikan pada penangas air goyang dengan kecepatan $160 \mathrm{rpm}, 24$ jam pada suhu $37^{\circ} \mathrm{C}$. Konsentrasi bakteri yang digunakan adalah $0,5 \mathrm{Mc}$ Farland (= 1,5 x 108 CFU $/ \mathrm{mL}$ ) (Henry, 1982 dalam Darusman et al., 1994).

Pengujian daya hambat bakteri secara invitro dilakukan dengan metode difusi agar. Cawan petri dibagi menjadi 6 bagian, dan masing-masing bagian diberi kode. Penanaman kultur bakteri uji dilakukan secara aseptis sebanyak $20 \mu \mathrm{L}$ ke dalam $15 \mathrm{~mL}$ media MHA dalam cawan petri, kemudian dibiarkan selama 10 menit sampai media memadat. Paperdisk diletakkan pada permukaan agar di setiap bagian petri yang telah diberi kode dan ditetesi dengan $20 \mu \mathrm{L}$ ekstrak picung sesuai dengan kode perlakuan. Kemudian cawan petri tersebut diinkubasikan dalam posisi terbalik pada inkubator pada suhu $37^{\circ} \mathrm{C}$ selama 24 jam (Anon., 2007)

\section{Penandaan zona hambatan}

Aktivitas daya hambat bakteri dinyatakan berdasarkan zona bening yang dihasilkan di sekitar paperdisk. Diameter zona hambat pertumbuhan bakteri diukur dalam satuan $\mathrm{mm}$ dan dijadikan ukuran kuantitatif untuk ukuran zona hambat. Efektifitas dari bahan aktif, ditentukan oleh perbandingan diameter zona hambat dengan nilai standar (Anon., 2007). Aktivitas tersebut dikelompokkan menjadi 4 kategori yaitu : aktivitas lemah $(<5 \mathrm{~mm})$, sedang $(5-10 \mathrm{~mm})$, kuat $(>10-20 \mathrm{~mm})$, sangat kuat $(>20-30 \mathrm{~mm})$ (Morales et al., 2003).

\section{HASIL DAN BAHASAN}

\section{Aktivitas Daya Hambat Ekstrak N-heksana, Akuades dan Etanol $50 \%$ pada Biji Picung Terfermentasi}

Aktivitas daya hambat ekstrak n-heksana, akuades, dan etanol $50 \%$ dari biji picung terfermentasi dapat dilihat pada Tabel 1, 2, dan 3 berikut.

Tabel 1. Diameter rata-rata daerah hambat $(\mathrm{mm})$ dari ekstrak $\mathrm{n}$-heksana biji picung terfermentasi Table 1. The average diameter $(\mathrm{mm})$ of inhibition zone of fermented Pangium edule $n$-hexane extracts

\begin{tabular}{llllllllllll}
\hline \multirow{2}{*}{ No Jenis bakte ri/Kind of bacteria } & \multicolumn{8}{c}{ Konse ntrasi ekstrak/Extract concentration (mg/mL) } \\
\cline { 2 - 10 } & & $\mathbf{1 0}$ & $\mathbf{2 0}$ & $\mathbf{3 0}$ & $\mathbf{4 0}$ & $\mathbf{5 0}$ & $\mathbf{6 0}$ & $\mathbf{7 0}$ & $\mathbf{8 0}$ & KIm & LP \\
\hline 1 & M. morganii & nd & nd & nd & nd & nd & nd & nd & nd & 11.67 & nd \\
2 & M. diversus & nd & nd & nd & nd & nd & nd & nd & nd & 13.67 & nd \\
3 & M. testaceum & nd & nd & nd & nd & nd & nd & nd & nd & 11.30 & nd \\
4 & R. terigena & nd & nd & nd & nd & nd & nd & nd & nd & 11.33 & nd \\
5 & Enterobacter sp. & nd & nd & nd & nd & nd & nd & nd & nd & 11.33 & nd \\
6 & Staphylococcus sp. & nd & nd & nd & nd & nd & nd & nd & nd & 17.00 & nd \\
\hline
\end{tabular}

Keterangan/Note: $\mathrm{nd}=$ tidak terdeteksi, $\mathrm{KIm}=$ kloramfenikol, LP = larutan pengekstrak (kontrol negatif)/ $n d=$ not detected,$K I m=$ chloramphenicol, $L P=$ solvent (negative control)

Tabel 2. Diameter rata-rata daerah hambat $(\mathrm{mm})$ dari ekstrak akuades biji picung terfermentasi Table 2. The average diameter $(\mathrm{mm})$ of inhibition zone of fermented Pangium edule aquadest extracts

\begin{tabular}{llllllllllll}
\hline \multirow{2}{*}{ No Jenis bakteri/Kind of bacteria } & \multicolumn{7}{c}{ Konse ntrasi } & ekstrak/Extract concentration $(\mathbf{m g} / \mathbf{m L})$ \\
\cline { 2 - 10 } & $\mathbf{1 0}$ & $\mathbf{2 0}$ & $\mathbf{3 0}$ & $\mathbf{4 0}$ & $\mathbf{5 0}$ & $\mathbf{6 0}$ & $\mathbf{7 0}$ & $\mathbf{8 0}$ & KIm & LP \\
\hline 1 & M. morganii & nd & nd & nd & nd & nd & nd & nd & nd & 11.67 & nd \\
2 & M. diversus & nd & nd & nd & nd & nd & nd & nd & nd & 13.67 & nd \\
3 & M. testaceum & nd & nd & nd & nd & nd & nd & nd & nd & 11.30 & nd \\
4 & R. terigena & nd & nd & nd & nd & nd & nd & nd & nd & 11.33 & nd \\
5 & Enterobacter sp. & nd & nd & nd & nd & nd & nd & nd & nd & 11.33 & nd \\
6 & Staphylococcus sp. & nd & nd & nd & nd & nd & nd & nd & nd & 17.00 & nd \\
\hline
\end{tabular}

Keterangan/Note: $\mathrm{nd}=$ tidak terdeteksi, $\mathrm{KIm}=$ kloramfenikol, LP = larutan pengekstrak (kontrol negatif)/ $n d=$ not detected, $\mathrm{KIm}=$ chloramphenicol, $L P=$ solvent (negative control) 
Tabel 3. Diameter rata-rata daerah hambat $(\mathrm{mm})$ dari ekstrak etanol $50 \%$ biji picung terfermentasi Table 3. The average diameter $(\mathrm{mm})$ of inhibition zone of fermented Pangium edule $50 \%$ ethanol extracts

\begin{tabular}{llllllllllll}
\hline \multirow{2}{*}{ No Jenis bakte ri/Kind of bacteria } & \multicolumn{10}{c}{ Konsentrasi ekstrak/Extract concentration (mg/mL) } \\
\cline { 2 - 11 } & $\mathbf{1 0}$ & $\mathbf{2 0}$ & $\mathbf{3 0}$ & $\mathbf{4 0}$ & $\mathbf{5 0}$ & $\mathbf{6 0}$ & $\mathbf{7 0}$ & $\mathbf{8 0}$ & KIm & LP \\
\hline 1 & M. morganii & nd & nd & nd & nd & nd & nd & nd & nd & 11.67 & nd \\
2 & M. diversus & nd & nd & nd & nd & nd & nd & nd & nd & 13.67 & nd \\
3 & M. testaceum & nd & nd & nd & nd & nd & nd & nd & nd & 11.30 & nd \\
4 & R. terigena & nd & nd & nd & nd & nd & nd & nd & nd & 11.33 & nd \\
5 & Enterobacter sp. & nd & nd & nd & nd & nd & nd & nd & nd & 11.33 & nd \\
6 & Staphylococcus sp. & nd & nd & nd & nd & nd & nd & nd & nd & 17.00 & nd \\
\hline
\end{tabular}

Keterangan/Note: $\mathrm{nd}=$ tidak terdeteksi, $\mathrm{KIm}=$ kloramfenikol, LP = larutan pengekstrak (kontrol negatif)/ $n d=$ not detected,$K I m=$ chloramphenicol,$L P=$ solvent (negative control)

Dari Tabel 1, 2, dan 3 dapat dilihat bahwa ekstrak n-heksana, akuades, dan etanol $50 \%$ dari biji picung terfermentasi ternyata tidak memberikan efek penghambatan secara signifikan terhadap semua bakteri pada semua tingkat konsentrasi. Hal ini diduga karena senyawa yang dihasilkan bukan merupakan senyawa antibakteri, dan enzim glukosidase yang berperan dalam pelepasan asam sianida telah mengalami kerusakan akibat pemanasan sebelum proses fermentasi (Muchtadi, 1998 dalam Ismaini, 2007). Hasil ini sejalan dengan hasil penelitian Ismaini (2007) bahwa ekstrak akuades, etanol 50\%, dan n-heksana dari biji picung terfermentasi tidak menunjukkan daya hambat terhadap bakteri pembusuk yaitu Micrococcus luteus, Staphylococcus aureus, Alcaligenes eutrophus, Enterobacter aerogenes, Flavobacterium gleum, Pseudomonas fluorescens, Salmonella typhimurium, dan Serratia marcescens. Oleh karena itu, maka pembahasan mengenai aktivitas daya hambat selanjutnya dibatasi pada ekstrak biji picung segar.

\section{Aktivitas Daya Hambat Ekstrak N-heksana pada Biji Picung Segar}

Dari Tabel 4, dapat dilihat bahwa pada ekstrak n-heksana biji picung dalam bentuk segar tidak menghasilkan zona bening terhadap semua bakteri uji. Hal ini memperlihatkan bahwa ekstrak n-heksana ternyata tidak memberikan efek penghambatan terhadap semua bakteri. Diduga bahwa meskipun pada komponen fitokimia ekstrak n-heksana biji picung segar terdapat komponen steroid, triterpenoid, alkaloid, dan glikosida, namun kontak antara senyawa fitokimia tersebut terhalang oleh adanya minyak dan lemak dalam ekstrak n-heksana. Minyak dan lemak lainnya yang berukuran lebih besar, mengganggu proses difusi dan melindungi bakteri dari senyawa antibakteri, sehingga ekstrak n-heksana tidak cukup untuk berdifusi dan tidak mampu menghambat pertumbuhan bakteri (Naufalin, 2005).

\section{Aktivitas Daya Hambat Ekstrak Akuades pada Biji Picung Segar}

Uji daya hambat bakteri dengan media Mueller Hinton Agar pada ekstrak akuades biji picung segar dengan konsentrasi $40-80 \mathrm{mg} / \mathrm{mL}$ menghasilkan zona bening pada bakteri-bakteri uji M. morganii, M. diversus, $M$. testaceum, $R$. terigena, Enterobacter sp., dan Staphylococcus sp. seperti terlihat pada Tabel 5 .

Dari Tabel 5, terlihat bahwa ekstrak akuades biji picung segar memiliki daya hambat terhadap $M$. morganii dan $M$. diversus pada konsentrasi

Tabel 4. Diameter rata-rata daerah hambat $(\mathrm{mm})$ ekstrak $\mathrm{n}$-heksana biji picung segar Table 4. The average diameter $(\mathrm{mm})$ of inhibition zone of fresh Pangium edule $n$-hexane extract

\begin{tabular}{|c|c|c|c|c|c|c|c|c|c|c|c|}
\hline \multirow{2}{*}{ No } & \multirow{2}{*}{ Jenis bakteri/Kind of bacteria } & \multicolumn{10}{|c|}{ Konsentrasi ekstrak/Extract concentration ( $\mathrm{mg} / \mathrm{mL})$} \\
\hline & & 10 & 20 & 30 & 40 & 50 & 60 & 70 & 80 & KIm & LP \\
\hline 1 & M. morganii & nd & $\overline{\mathrm{nd}}$ & $\overline{\mathrm{nd}}$ & nd & nd & nd & $\overline{\mathrm{nd}}$ & nd & 8.67 & $\overline{\mathrm{nd}}$ \\
\hline 2 & M. diversus & nd & nd & nd & nd & nd & nd & nd & nd & 10.00 & nd \\
\hline 3 & M. testaceum & nd & nd & nd & nd & nd & nd & nd & nd & 9.00 & nd \\
\hline 4 & R. terigena & nd & nd & nd & nd & nd & nd & nd & nd & 11.00 & nd \\
\hline 5 & Enterobacter sp. & nd & nd & nd & nd & nd & nd & nd & nd & 8.67 & nd \\
\hline 6 & Staphylococcus sp. & nd & nd & nd & nd & nd & nd & nd & nd & 12.33 & nd \\
\hline
\end{tabular}

Keterangan/Note: $\mathrm{nd}=$ tidak terdeteksi, $\mathrm{KIm}=$ kloramfenikol, $\mathrm{LP}=$ larutan pengekstrak (kontrol negatif)/ $n d=$ not detected,$K I m=$ chloramphenicol,$L P=$ solvent (negative control) 
Tabel 5. Diameter rata-rata daerah hambat $(\mathrm{mm})$ ekstrak akuades biji picung segar Table 5. The average diameter $(\mathrm{mm})$ of inhibition zone of fresh Pangium edule aquadest extract

\begin{tabular}{|c|c|c|c|c|c|c|c|c|c|c|c|}
\hline \multirow{2}{*}{ No } & \multirow{2}{*}{$\begin{array}{l}\text { Jenis bakteri/ } \\
\text { Kind of bacteria }\end{array}$} & \multicolumn{10}{|c|}{ Konsentrasi ekstrak/Extract concentration ( $m g / m L)$} \\
\hline & & 10 & 20 & 30 & 40 & 50 & 60 & 70 & 80 & $\mathrm{KIm}$ & $\mathbf{L P}$ \\
\hline 1 & M. morganii & nd & $\overline{\mathrm{nd}}$ & nd & nd & 1.00 & 0.83 & $\overline{2.33}$ & 3.33 & 11.33 & nd \\
\hline 2 & M. diversus & nd & nd & nd & nd & 0.67 & 1.00 & 2.00 & 1.33 & 6.67 & nd \\
\hline 3 & M. testaceum & nd & nd & nd & 1.33 & 0.67 & 0.67 & 0.83 & 3.00 & 10.67 & nd \\
\hline 4 & R. terigena & nd & nd & nd & 0.50 & 0.75 & 1.00 & 1.50 & 2.50 & 10.00 & nd \\
\hline 5 & Enterobacter sp. & nd & nd & nd & 1.00 & 0.67 & 1.17 & 1.00 & 2.00 & 8.33 & nd \\
\hline 6 & Staphylococcus sp. & nd & nd & nd & 2.33 & 4.67 & 5.33 & 9.33 & 12.00 & 19.67 & nd \\
\hline
\end{tabular}

Keterangan/Note: $\mathrm{nd}=$ tidak terdeteksi, $\mathrm{KIm}=$ kloramfenikol, $\mathrm{LP}=$ larutan pengekstrak (kontrol negatif)/ $n d=$ not detected, $\mathrm{KIm}=$ chloramphenicol, $L P=$ solvent (negative control)

$50 \mathrm{mg} / \mathrm{mL}$ atau lebih, sedangkan M. testaceum, $R$. terigena, Enterobacter sp., dan Staphylococcus sp. mulai dihambat pada konsentrasi $40 \mathrm{mg} / \mathrm{mL}$. Zona bening tertinggi pada $M$. morganii dihasilkan oleh ekstrak akuades biji picung segar pada konsentrasi $80 \mathrm{mg} / \mathrm{mL}(3,33 \mathrm{~mm})$, M. diversus pada konsentrasi $70 \mathrm{mg} / \mathrm{mL}(13 \mathrm{~mm})$, M. testaceum pada konsentrasi $80 \mathrm{mg} / \mathrm{mL}(3 \mathrm{~mm}), R$. terigena pada konsentrasi $80 \mathrm{mg} / \mathrm{mL}(2,5 \mathrm{~mm})$, Enterobacter sp. pada konsentrasi $80 \mathrm{mg} / \mathrm{mL}(2 \mathrm{~mm})$, dan Staphylococcus sp. pada konsentrasi $80 \mathrm{mg} / \mathrm{mL}(12 \mathrm{~mm})$. Dapat dikatakan bahwa zona bening tertinggi untuk semua bakteri uji dihasilkan oleh ekstrak akuades dengan konsentrasi $80 \mathrm{mg} / \mathrm{mL}$, meskipun pada konsentrasi ini, zona bening ekstrak akuades biji picung segar yang terbentuk masih lebih kecil dari zona bening kloramfenikol. Ekstrak akuades biji picung segar dapat menghambat pertumbuhan bakteri tersebut, diduga karena mengandung senyawa antibakteri seperti : senyawa fenol, flavonoid, alkaloid, tanin, dan senyawa anionik. Ismaini (2007) melaporkan biji picung segar yang diekstraksi dengan akuades mengandung senyawa golongan alkaloid, flavonoid, dan saponin yang memiliki aktivitas antibakteri. Mekanisme penghambatan flavonoid terhadap pertumbuhan bakteri diduga karena kemampuan senyawa tersebut membentuk komplek dengan protein ekstraselular, menginaktivasi enzim, dan merusak membran sel. Pada umumnya senyawa flavonoid dapat menghambat pertumbuhan bakteri Gram positif dan Gram negatif (Cowan, 1999).

Berdasarkan diameter zona hambat, maka dapat diketahui bahwa aktivitas daya hambat ekstrak akuades biji picung segar terhadap $M$. morganii, $M$. diversus, $M$. testaceum, $R$. terigena, dan Enterobactersp. termasuk aktivitas lemah, sedangkan terhadap Staphylococcus sp. termasuk kategori aktivitas lemah pada konsentrasi $40-50 \mathrm{mg} / \mathrm{mL}(2,33$ $4,67 \mathrm{~mm}$ ) sampai kuat pada konsentrasi $80 \mathrm{mg} / \mathrm{mL}$.

Ekstrak akuades biji picung segar mempunyai kemampuan penghambatan paling tinggi pada Staphylococcus sp., kemudian berturut-turut diikuti oleh M.morganii, M. testaceum, R. terigena, dan Enterobacter sp. Sedangkan bakteri uji yang paling sulit dihambat adalah $M$. diversus. Hal ini menunjukkan bahwa bakteri yang paling sensitif terhadap ekstrak biji picung segar adalah Staphylococcus sp.

\section{Aktivitas Daya Hambat Ekstrak Etanol 50\% pada Biji Picung Segar}

Pada Tabel 6 terlihat bahwa ekstrak etanol $50 \%$ biji picung segar tidak dapat menghambat pertumbuhan M. morganii dan Enterobacter sp. pada

Tabel 6. Diameter rata-rata daerah hambat $(\mathrm{mm})$ ekstrak etanol $50 \%$ biji picung segar Table 6. The average diameter $(\mathrm{mm})$ of inhibited zone of fresh Pangium edule ethanol extract

\begin{tabular}{llccccccccccc}
\hline \multirow{2}{*}{ No } & Jenis bakteri/ & \multicolumn{4}{c}{ Konse ntrasi ekstrak/Extract concentration $(\mathbf{m g} / \mathbf{m L})$} \\
\cline { 3 - 11 } & \multicolumn{1}{c}{ Kind of bacteria } & $\mathbf{1 0}$ & $\mathbf{2 0}$ & $\mathbf{3 0}$ & $\mathbf{4 0}$ & $\mathbf{5 0}$ & $\mathbf{6 0}$ & $\mathbf{7 0}$ & $\mathbf{8 0}$ & KIm & LP \\
\hline 1 & M. morganii & nd & nd & 0.33 & 14.00 & 9.33 & 14.67 & 12.67 & 18.00 & 19.33 & nd \\
2 & M. diversus & 0.33 & 0.33 & 1.33 & 11.33 & 7.00 & 12.33 & 7.00 & 13.00 & 17.00 & nd \\
3 & M. testaceum & 0.67 & 0.67 & 0.67 & 13.00 & 9.00 & 17.00 & 11.00 & 16.33 & 22.33 & nd \\
4 & R. terigena & 0.33 & 0.33 & 0.67 & 12.00 & 6.67 & 14.00 & 12.00 & 15.67 & 20.33 & nd \\
5 & Enterobacter sp. & nd & nd & nd & 18.00 & 7.33 & 13.33 & 9.00 & 15.00 & 18.00 & nd \\
6 & Staphylococcus sp. & 0.33 & 0.67 & 1.00 & 12.00 & 6.33 & 13.00 & 10.67 & 16.67 & 20.00 & nd \\
\hline
\end{tabular}

Keterangan/Note: $\mathrm{nd}=$ tidak terdeteksi, $\mathrm{KIm}=$ kloramfenikol, LP = larutan pengekstrak (kontrol negatif)/ $n d=$ not detected, $\mathrm{KIm}=$ chloramphenicol, $L P=$ solvent (negative control) 
konsentrasi $10-20 \mu \mathrm{g} / \mathrm{mL}$ diduga karena ekstrak tersebut konsentrasinya masih rendah dan belum bersifat toksik terhadap sel bakteri, sehingga tidak merusak membran sel dan mengganggu proses biosintesis peptidoglikan (Cowan, 1999).

Pada ekstrak etanol biji picung segar, diameter zona bening yang terbentuk pada konsentrasi $80 \mathrm{mg} / \mathrm{mL}$ hampir mendekati diameter zona bening kloramfenikol terhadap bakteri uji $M$. morganii, $M$. diversus, dan R. terigena. Penghambatan ekstrak etanol $50 \%$ terhadap keenam bakteri uji sebesar 0,33 $-18 \mathrm{~mm}$ pada konsentrasi $30-80 \mu \mathrm{g} / \mathrm{mL}$.

Mengacu pada Tabel 6 dapat dikatakan bahwa konsentrasi ekstrak etanol $50 \%$ yang efektif menghambat pertumbuhan bakteri $M$. morganii, $M$. diversus, $R$. terigena, dan Staphylococcus sp. adalah konsentrasi $80 \mathrm{mg} / \mathrm{mL}$. M. testaceum dihambat pada konsentrasi $60 \mathrm{mg} / \mathrm{mL}$, sedangkan Enterobacter sp. dihambat pada konsentrasi $40 \mathrm{mg} / \mathrm{mL}$.

Ekstrak etanol $50 \%$ biji picung segar memiliki daya hambat terhadap $M$. morganii pada konsentrasi 30 $\mathrm{mg} / \mathrm{mL}$ atau lebih, Enterobactersp. pada konsentrasi $40 \mathrm{mg} / \mathrm{mL}$ atau lebih, sedangkan $M$. diversus, M. testaceum, R. terigena, dan Staphylococcus sp. mulai dihambat pada konsentrasi $10 \mathrm{mg} / \mathrm{mL}$. Berdasarkan diameter zona hambat, maka dapat diketahui bahwa aktivitas antibakteri ekstrak etanol $50 \%$ biji picung segar terhadap $M$. morganii, $M$. diversus, $M$. testaceum, $R$. terigena, dan Staphylococcus sp. termasuk aktivitas lemah sampai kuat, sedangkan aktivitasnya terhadap Enterobacter $\mathrm{sp}$. termasuk aktivitas sedang sampai kuat.

Ekstrak etanol $50 \%$ biji picung segar memiliki kemampuan penghambatan paling tinggi terhadap M. morganii dan Enterobacter sp., kemudian berturutturut diikuti oleh $M$. testaceum, Staphylococcus sp., dan $R$. terigena. Sementara itu bakteri yang paling sulit dihambat adalah $M$. diversus. Dengan demikian dapat diketahui bahwa bakteri yang paling sensitif terhadap ekstrak etanol $50 \%$ biji picung segar adalah $M$. morganii dan yang paling resisten adalah M. diversus.

Ekstrak etanol memberikan daya hambat lebih tinggi daripada ekstrak akuades. Diduga ekstrak etanol $50 \%$ lebih memberikan polaritas optimum daripada ekstrak akuades. Menurut Kanazawa et al. (1995) dalam Naufalin (2005) suatu senyawa yang mempunyai polaritas optimum akan mempunyai aktivitas antimikroba maksimum, karena untuk interaksi suatu senyawa antibakteri dengan bakteri diperlukan keseimbangan hidrofilik-lipofilik. Sifat hidrofilik diperlukan untuk menjamin senyawa larut dalam fase air yang merupakan tempat hidup mikroba, tetapi senyawa yang bekerja pada membran sel hidrofobik memerlukan pula sifat lipofilik, sehingga senyawa antibakteri memerlukan keseimbangan hidrofilik-hidrofobik untuk mencapai aktivitas yang optimal (Branen \& Davidson, 1993 dalam Naufalin et al., 2005). Selain itu, ekstrak etanol 50\%, jika dibandingkan dengan ekstrak akuades, menunjukkan aktivitas yang lebih kuat. Hal ini diduga dengan pelarut etanol komponen senyawa aktif pada biji picung segar akan lebih banyak terekstrak. Andarwulan (1999) menyatakan pelarut etanol $50 \%$ merupakan pelarut yang baik untuk menarik senyawa golongan polifenol (tanin), fenol, glikosida, dan flavonoid dari tumbuhan.

\section{KESIMPULAN}

1. Pada biji picung terfermentasi, baik ekstrak akuades, etanol $50 \%$, maupun n-heksana tidak mampu menghambat pertumbuhan bakteri penghasil histamin.

2. Pada biji picung segar, ekstrak n-heksana tidak memberikan penghambatan secara signifikan terhadap semua bakteri uji.

3. Ekstrak akuades biji picung segar memiliki daya hambat terhadap $M$. morganii dan $M$. diversus pada konsentrasi $50 \mathrm{mg} / \mathrm{mL}$ atau lebih, sedangkan M. testaceum, R. terigena, Enterobactersp., dan Staphylococcus sp. mulai dihambat pada konsentrasi $40 \mathrm{mg} / \mathrm{mL}$. Berdasarkan aktivitas daya hambatnya, ekstrak akuades biji picung segar memberikan aktivitas lemah terhadap $M$. morganii, $M$. diversus, M. testaceum, R. terigena, dan Enterobacter sp., serta memiliki aktivitas lemah sampai kuat terhadap Staphylococcus sp.

4. Ekstrak etanol $50 \%$ biji picung segar pada konsentrasi $10-20 \mathrm{mg} / \mathrm{mL}$ tidak memiliki daya hambat, namun pada konsentrasi $30 \mathrm{mg} / \mathrm{mL}$ atau lebih memiliki daya hambat terhadap M. morganii, M. diversus, M. testaceum, $R$. terigena, dan Staphylococcus sp. kecuali pada Enterobacter sp. Berdasarkan aktivitas daya hambatnya, ekstrak etanol $50 \%$ biji picung segar memiliki aktivitas lemah sampai kuat terhadap M. morganii, M. diversus, M. testaceum, $R$. terigena, dan Staphylococcus sp., sedangkan aktivitasnya terhadap Enterobacter sp. termasuk kategori sedang sampai kuat. Zona bening yang terbentuk pada Enterobacter sp. pada konsentrasi $40 \mathrm{mg} / \mathrm{mL}$ hampir mendekati diameter zona bening kloramfenikol.

5. Secara umum ekstrak etanol $50 \%$ lebih baik daripada ekstrak akuades karena memberikan daya hambat terhadap pertumbuhan bakteri pembentuk histamin yang lebih tinggi. 


\section{DAFTAR PUSTAKA}

Aminah. 2008. Potensi Pangium edule Reinw (picung) sebagai agen pengendali hayati, Tahap II. http:// www.ekologi.litbang.depkes.go.id/data/abstrak/ nunik2.pdf. Diakses tanggal 3 April 2008.1 pp.

Anonim. 1995. Farmakope Indonesia, Edisi IV. Ditjen POM, Departemen Kesehatan R.I., Jakarta. 1290 pp.

Anonim. 2008. Kepayang. http://bebas.v/sm.org/v12/ artikel/ttg tanaman obat/depkes/buku1/1-217.pdf. Diakses tanggal 3 April $2008.1 \mathrm{pp}$.

Anonymous. 2007. Chemical methods of cultural classroom activity. Access excellence classic collection. http: //www. accesexcellence.org/AE/AEC/CC/ chance_activity.html. Diakses tanggal 3 Desember 2007. 1 pp.

Akiyama, H., Fuji, K., Yamasaki, O., Oono, T., and Iwatsuki, K. 2001. Antibacterial action of several tannins against Staphylococcus aureus. J. of Antimicrobial Chemotherapy Lawrence. 48: 487-491.

Andarwulan, N., Fardiaz, S., Waimena, G.A., and Shetty, K. 1999. Antioxidant activity associate with lipid and phenolic mobilization during seed germination of Pangium edule Reinw. J. Agric. Food Chemistry. 47: 3158-3163.

Cowan, M.M. 1999. Plant products as antimicrobial agents. Clinical Microbiology Reviews. 12(4): 564582.

Darusman, L.K., Sajuthi, D., Sutriah, K., dan Pamungkas, D. 1994. Ekstraksi komponen bioaktif sebagai bahan obat dari kerang-kerangan, bunga karang dan ganggang di Perairan P. Pari, Kepulauan Seribu tahap II : Fraksinasi dan Bioassay. Makalah Seminar Nasional Hasil-hasil Penelitian. DIKTI, Depdikbud. $29 \mathrm{pp}$.

Harborne, J.B. 1998. Phytochemical Methods. A Guide to Modern Techniques of Plants Analysis. Third edition. Chapman \& Hall, London. 302 pp.

Indriyati. 1987. Mempelajari Aktivitas Antibakterial Biji Picung (Pangium edule Reinw.) Terhadap Beberapa Bakteri Pembusuk Ikan Secara Invitro. Skripsi. Fakultas Teknologi Pertanian, Institut Pertanian Bogor. $61 \mathrm{pp}$.

Indriati, N., Rispayeni, dan Heruwati, E.S. 2006. Studi bakteri pembentuk histamin pada ikan kembung peda selama proses pengolahan. J. Penel. Perik. Indonesia. 1(2): 117-123.

Ismaini, L. 2007. Studi Aktivitas dan Analisis Kimia Senyawa Antibakteri dari Ekstrak Biji Picung (Pangium edule Reinw.). Tesis. Program Pascasarjana Fakultas MIPA, Universitas Indonesia. $87 \mathrm{pp}$.
Jay, W.C. 1996. Modern Food Microbiology. $4^{\text {th }}$.ed. International Thompson Publishing. $661 \mathrm{pp}$.

Morales, G., Sierra, P., Mancilla, Paredes, A., Loyola, L. A., Gallardo, O., and Borquez, J. 2003. Secondary metabolites from four medicinal plants from Northern Chile, antimicrobial activity, and biotoxicity against Artemia salina. J. Chile Chem. 48(2).

Nahla, Korashy, T., and Farag, H.S.M. 2005. Histamine and histamine producing bacteria in some local and imported fish and their public health significance. Res J. Agr. \& Bio. Sci. 1(4): 329-336.

Naufalin, R. 2005. Kajian Sifat Antimikroba Ekstrak Bunga Kecombrang (Nicolaia speciosa Horan) Terhadap Berbagai Mikroba Patogen dan Perusak Pangan. Disertasi. Sekolah Pascasarjana, Institut Pertanian Bogor.

Naufalin, R., Jenie, B.S.L., Kusnandar, F., Sudarwamto, M., dan Rukmini, H. 2005. Aktivitas antibakteri ekstrak bunga kecombrang terhadap bakteri patogen dan perusak pangan. Jurnal. Teknol. dan Industri Pangan. 16(2): 119-125.

Niven, C.F., Jeffrrey, M.B., and Corlett, D.A. 1981. Differential plating medium for quantitative detection of histamine producing bacteria. Applied and Environmental Microbiology. p. 321-322.

Rispayeni. 2005. Bakteri Pembentuk Histamin pada Peda Kembung Perempuan (Rastrelliger neglectus) Selama Proses Pengolahan. Skripsi Sarjana Sains. Fakultas Biologi, Universitas Nasional, Jakarta. 55 pp.

Sally. H.A., Price, R.S., and Brown, W. 1980. Histamine formation by bacteria isolated from skipjack tuna. Bulletin of the Japanese Society of Scientific Fisheries. 46: 991-995.

Sophia, R.A. 2007. Seleksi dan Pengujian Aktivitas Enzim L-Histidine Decarboxylase dari Bakteri Pembentuk Histamin. Tesis. Fakultas MIPA, Universitas Indonesia. $71 \mathrm{pp}$.

Wangidjaja, R.G. 2004. Ekstrak Bunga dan Getah Semboja Sebagai Antibakteri dan Bahan Aktif untuk Pergeseran Gigi Seri Kelinci. Disertasi. Sekolah Pascasarjana, Institut Pertanian Bogor. 110 pp.

Widyasari, R.A.H.E. 2005. Teknologi Pengawetan Ikan Kembung (Rastreliger brachysoma) Segar Dengan Menggunakan Bahan Bioaktif Alami Biji Picung (Pangium edule Reinw). Tesis. Sekolah Pascasarjana, Institut Pertanian Bogor.

Witiak, D.T., Jeffrey, M.B., and Corlett, D.A. 1981. Antiallergenic agents. In. Foye, W. O. (ed). Principles of Medicinal Chemistry. LEA \& Febiger, Philadelphia. $474 \mathrm{pp}$. 
